\title{
ВИВЧЕННЯ ФІТОРІЗНОМАНІТТЯ ДОЛИНИ РІЧКИ СИРОВАТКА З ПЕРСПЕКТИВОЮ ВИКОРИСТАННЯ Ї̈ ПРИРОДНИХ КОМПЛЕКСІВ В ЕКОЛОГІЧНОМУ ТУРИЗМІ
}

Скляр Вікторія Григорівна

доктор біологічних наук, професор

Сумський національний аграрний університет, м. Суми, Україна

ORCID: 0000-0002-1301-7384

skvig@ukr.net

Тихонова Олена Михайлівна

кандидат біологічних наук, доцент

Сумський національний аграрний університет, м. Суми, Україна

ORCID: 0000-0003-0961-4896 ur5apn@ukr.net

Кирильчук Катерина Серіївна кандидат біологічних наук, доцент Сумський національний аграрний університет, м. Суми, Україна ORCID: 0000-0001-9968-4833 ekaterinakir2017@gmail.com

Клименко Ганна Олександрівна кандидат біологічних, доцент Сумський національний аграрний університет, м. Суми, Україна ORCID: 0000-0003-1859-4997 annaklimenko2014@gmail.com

Онопрієнко Володимир Петрович доктор педагогічних наук, професор Сумський національний аграрний університет, м. Суми, Україна onoprienko.v.p@ukr.net

Бондарєва Людмила Миколаївна кандидат біологічних наук, доцент Сумський національний аграрний університет, м. Суми, Україна ORCID: 0000-0003-4126-7601 milabond77@gmail.com

Троцька Світлана Сергіївна кандидат біологічних наук, ст. викладач Сумський національний аграрний університет, м. Суми, Україна ORCID: 0000-0003-2089-5780 s.s.trotska@gmail.com

Клименко Юлія Олександрівна студентка

Сумський національний аграрний університет, м. Суми, Україна klimenkou147@gmail.com

В роботі представлені результати вивчення фіторізноманіття природних комплексів ділянки долини річки Сироватки між селами Верхня Сироватка та Новоселиця Сумського району. Показано, що цій території притаманне значне видове різноманіття, яке представлене рослинами, що мають різні ранги охорони (регіональний, державний і міжнародний). Група рослин міжнародного рангу охорони є найбільшою і включає близько 50 видів. її фрормують рослини, включені до «Червоного списку МСОП». Майже усі вони (окрім одного) мають невисокий охоронний статус (LC - знаходяться під найменшою загрозою). Із числа видів, включених до «Червоної книги України», виявлено небагаточисельну популяцію Iris pineticola Klokov, а із рослин, представлених у «Переліку видів, які підлягають особливій охороні на території Сумської області» - Salix rosmarinifolia L. ma Crataegus ucrainica Pojark. 
Значним є і ценотичне різноманіття, репрезентоване угрупованнями водної, повітряно-водної, лучної та лісової рослинності. Багате фріторізноманіття у комплексі із рівнинністю території та білизкістю до населених пунктів, у тому числі і до м. Суми, формують об'єктивне підгрунтя щодо залучення цієї території до туристичної, рекреаційної та еколого-просвітницької діяльності. Найбільш перспективним є впровадження екологічного туризму, який пов'язує у собі питання економічного, соціального та екологічного характерів. 3 метою поглиблення знань про фрормування, сучасний стан та динаміку розвитку природних комплексів долини річки Сироватки, необхідно продовжити геоботанічні та зоологічні дослідження даної території. Окрім того, доцільно привести лісовий масив в естетично-привабливий стан, зокрема, видалити смітники з подальшим облаштуванням рекреаційних зон. 3 врахуванням багатого біорізноманіття території доцільно розглянути і питання щодо надання їй природохоронного статусу з обранням категорії, яка дозполить як поліпшити охорону рослинного і тваринного світу, так і надасть можливість реалізовувати рекреаційну та туристичну діяльність.

Ключові слова: фріторізноманіття, навколишнє природне середовище, екологічний туризм, екологія людини, природні ландшасрти.

\section{DOI https://doi.org/10.32845/agrobio.2021.3.6}

Вступ. На сучасному етапі розвитку туристичної галузі одним із пріоритетних напрямів сталого розвитку територій став екологічний туризм. Туристичний сектор $€$ висококонкурентним середовищем, яке змушує туроператорів надавати кращі послуги для відвідувачів, щоб залишатися конкурентоспроможними (Barkin, 2002; Bashtovyi et al., 2018). В екологічному туризмі, ніша якого постійно розширюється на туристичному ринку, біотичні та абіотичні компоненти навколишнього середовища відіграють вирішальну роль у сприянні стійкості та конкурентоспроможності цього напряму. Серед провідних мотивів туристських подорожей на перший план виступає прагнення людей до відпочинку в лоні природи. Звідси походить вислів «soft tourism», що означає «м'який туризм» - туризм з м'яким дотиком до природи. Екологічний та сільський зелений туризм тісно пов'язані з екологією людини, адже певною мірою вирішують проблему її реабілітації та емоційного оздоровлення. Дослідження низки вчених доводять, що естетика ландшафртного фоторізноманіття чинить позитивний психологічний вплив на емоційний і соматичний стан людини (Skrebets, 2005; Copylets, 2009; L'ovochkina, 2003). Окрім того, екологічний туризм з його великими рекреаційними і пізнавальними можливостями покликаний сформувати суспільну свідомість щодо охорони та раціонального використання природних багатств, донести до людей актуальність і важливість питання захисту навколишнього середовища від антропогенних впливів. У провідних країнах світу екологічний туризм стає супутником і невід'ємною частиною всіх видів туризму, є регулятивним важелем управління раціональним природокористуванням, завдяки просвітницькому потенціалу (Dmytruk, 2002; Kozenja, 2005; Honey, 2008). Окрім того, екотуризм може сприяти розвитку економічної складової регіону (Hunt, 2015).

Деякі автори відносять екологічний туризм до пізнавального відпочинку на природоохоронних територіях, але більшість дослідників вважають, що розвиток цієї галузі покликаний вирішити екологічні проблеми природних ландшафтів, адже одним із ключових аспектів глобальних змін є зниження їх екологічної цілісності (Burger \& Joanna, 2000). Колишні ліси і заплавні луки як осередки біорізноманіття та екосистеми, які мігруючі тварини використовують в якості тимчасових притулків, перетворюються на мозаїку деградованих ділянок. Руйнування місць існування видів неухильно веде до зниження біорізноманіття окремих екосистем і біосфери у цілому, що є однією з глобальних проблем людства, вирішенню якої присвячена значна кількість наукових праць (Dupuy \& Viñuales, 2018; Wilsey, 2018; Salk et al., 2020; Kaur, 2018; Sui et al., 2018; Rahman, 2018; Segelbacher, 2018; Cardinale et al., 2011; Mace et al., 2012). Якщо ситуація не зміниться, біорізноманіття неухильно буде знижуватись навіть на природоохоронних територіях. Саме орієнтацією на екологічну складову пояснюється підвищена увага в останні роки до відвідування заповідних ділянок природи або місць із малозміненим природним середовищем (Skliar, 2014).

В світі існує дві моделі екологічного туризму - австралійська, де організація туризму відбувається у межах дикої природи та західноєвропейська, коли подорожі проводяться у межах природоохоронних територій. В Україні пріорітетною моделлю розвитку екотуризму $€$ остання (Posohov \& Sagaidachna, 2019). Одним із найважливіших екологічних завдань країни є збереження біорізноманіття рослинного та тваринного світу на заповідних територіях та природних ландшафтах без охоронного статусу, які слугують екологічними коридорами для мігруючих тварин (Skliar et al., 2012; Bondarieva et al., 2019; Klymenko et al., 2011). За умов раціонального підходу до організаційних питань, екологічний туризм може покращити стан природних ландшафтів як середовища існування рідкісних видів тварин та рослин. Відповідно, виявлення територій із багатим біорізноманіттям, що $є$ перспективними для використання у сфері екологічного туризму, є актуальним питанням, яке має вагоме соціальне зачення.

Матеріали і методи досліджень. До числа територій, перспективних для використання в екологічному туризмі, належать долини малих річок і, зокрема, р. Сироватка, яка протікає по території Сумського району Сумської області і $є$ лівою притокою р. Псел. Протягом 2019-2020 років було здійснене вивчення природних комплексів долини цієї річки у межах ділянки, яка охоплює територію між селами Верхня Сироватка та Новоселиця (рис. 1). Теоретичні методи базувалися на аналізі наукової літератури з проблематики дослідження і супроводжувалися систематизацією, класифікацією та узагальненням літературних даних (Sheljag-Sosonko, 1971; Skliar et al., 2020; Korovjakova et al., 2015). В ході 
польових досліджень проводилось натурне обстеження території, визначалися типові угруповання, які репрезентують видове різноманіття долини р. Сироватки. В процесі роботи були використані стандартні групи методів: спостереження, аналітичний, картографічний, статистичний. В камеральних умовах було здійснено обробку гербарного матеріалу, а також проведено визначення належності описаних екотопів до територій, перспективних для використання в екологічному туризмі.

Результати. За фрізико-географічним районуванням України досліджуваний регіон знаходиться у межах Східно-Європейської рівнини, в Лісостеповій природній зоні, Східно-Українському краю, в Сумській схилово-височинній області. За геоботанічним районуванням територія дослідження знаходиться в Сумському геоботанічному окрузі кленово-липово-дубових, липово-дубових, дубових, дубово-соснових лісів і лучних степів (Marynych, 2003). Його геологічні умови визначаються положенням на північному схилі Дніпровсько-Донецької западини, де докембрійський кристалічний фундамент знаходиться на глибинах від 0,5 до 3,0 км. На докембрійському фундаменті залягають товщі осадових порід від девонських до четвертинних. Найбільш давніми з них, які виходять на поверхню, є крейдові мергелі та глини, піски. Антропогенові відклади представлені лесами і лесоподібними суглинками, водно-льодовиковими суглинками і пісками, давньоозерними утвореннями, алювіальними й еоловими піщаними відкладами (Sobolev, 1947).

Нині, як і у геологічному минулому, потужним чинником формування природних комплексів та їх важливим компонентом виступають поверхневі води. Результатом їхньої діяльності $€$ формування долин річок, а також геологічних відкладів певного складу та потужності. Ці ж дві характеристики, у свою чергу, відбиваються на стані ландшафтів. Долина р. Сироватки представлена природними комплексами терасових горбистих піщаних рівнин з дерново-підзолистими ґрунтами, з борами і суборами по корінному берегу та широкою заплавою. На лучно-болотних заплавних рівнининах, переважно на лучних і лучно-болотних ґрунтах та опідзолених чорноземах на лесових суглинках, поширені сильноі середньозволожені різнотравні та осокові луки, вербняки, вільшняки, осичники. У середній частині заплави луки - різнотравні та подекуди осокові. Притерасна заплава зайнята осоковими, різнотравно-осоковими луками, вільшняками. У заплавах наявні старичні озера, заболочені левади із водно-болотною рослинністю.

Одна з найцінніших ділянок луків разом із болотами, озером і корінним берегом простягається у межах території дослідження. Ці низинні луки ніколи не оброблялися людиною, через що збереглося їх унікальне біорізноманіття. Ліси, що увійшли до складу обстежуваної теритоpiї, є складним поєднанням штучних посадок і змінених природних комплексів. Важливою складовою території $€$ річка, яка перетинає її зі сходу на захід. Ширина водотоку здебільшого становить 5-6 м. Водойма є місцем формування угруповань із домінуванням рослин-макрофрітів. На поверхні води у невеликих заводях сформувалися популяції ряски малої (Lemna minor L.)* серед яких трапляються поодинокі рослини спіродели багатокореневої (Spirodella polyrrhiza (L.) Schleid.)*. У воді спостерігаються зарості куширу зануреного (Ceratophyllum demersum L.) ${ }^{*}$ та водяного жовтеця водного (Batrachium aquatile (L.) Dumort.)*. У північній частині озера, яке сформувалося у результаті поглиблення стариці задля видобутку піску, знаходиться рясне угруповання глечиків жовтих (Nuphar lutea (L.) Sm.)* із проективним покриттям 25-30\%.

У прибережній зоні водойм домінують рогіз широколистий (Typha latifolia L.)*, очерет звичайний (Phragmites australis (Cav.) Trin. Ex Steud.)* та сусак зонтичний (Butomus umbellatus L.)*, спорадично трапляється частуха подорожникова (Alisma plantago-aquatica L.)*, куга озерна (Schoenoplectus lacustris (L.) Palla)*, жабурник звичайний (Hydrocharis morsus-ranae L.)*. По берегах

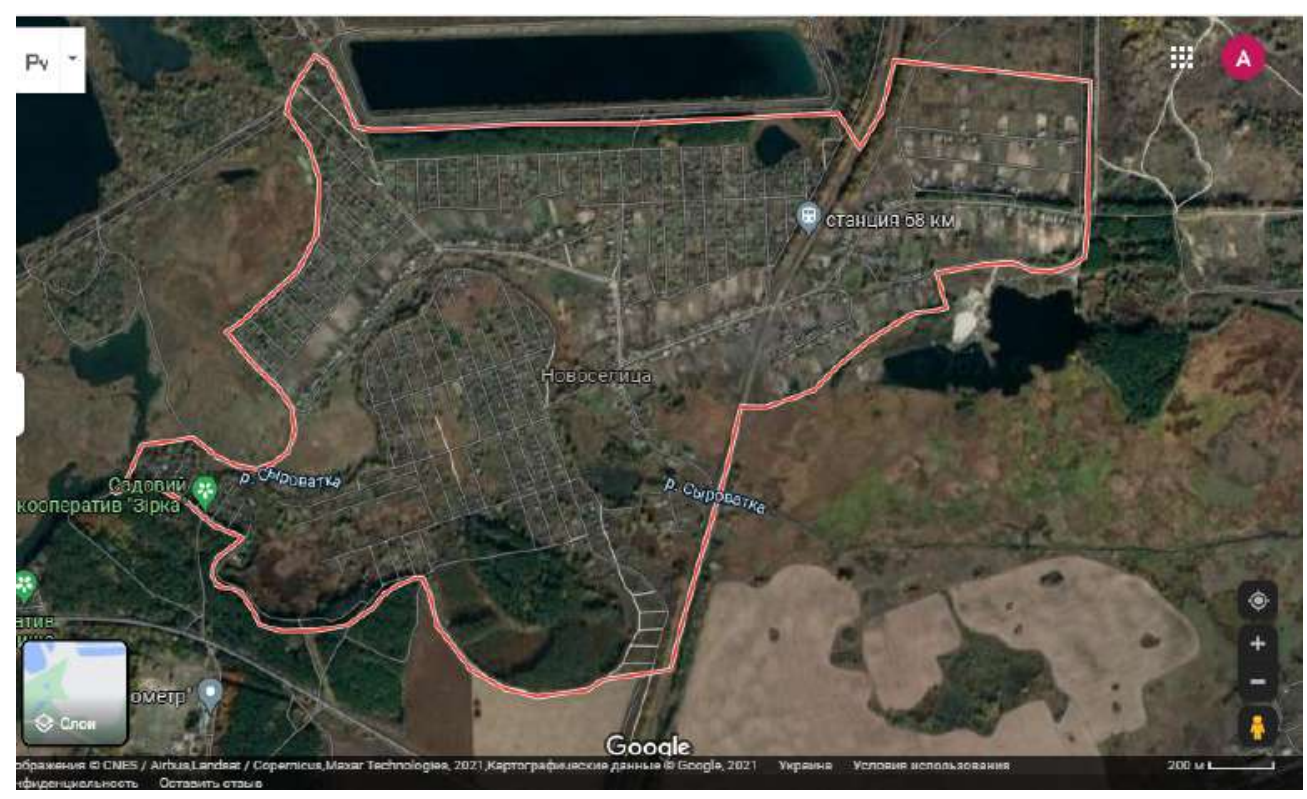

Рис. 1. Долина р. Сироватка між селами Верхня Сироватка та Новоселиця 
річки розкинулися зарості гірчака почечуйного (Persicaria maculosa Grey.) ${ }^{*}$ з проективним покриттям 60 \% та сідача коноплевого (Eupatorium cannabinum L.). Прибережна рослинність представлена різноманіттям таких гідрофільних видів як комиш лісовий (Scirpus sylvaticus L.) ${ }^{*}-10 \%$, осока побережна (Carex riparia Curtis)*, осока гостровидна (Carex acutiformis Ehrh.) ${ }^{*}$, хвощ річковий (Equisetum fluviatile L.)*, зніт болотний (Epilobium palustre L.)*, череда трироздільна (Bidens tripartita L.)*, зірочник болотяний (Stellaria palustris Ehrh. Ex Hoffm.), вероніка струмкова (Veronica beccabunga L.)*, слабник водяний (Myosoton aquaticum (L.) Moench.), ситник жаб'ячий (Juncus bufonius L.)*. Тут також зростають тонконіг лучний (Poa pratensis L.)*, перстач гусячий (Potentilla anserina L.)*, конюшина повзуча (Trifolium repens L.), вовконіг європейський (Lycopus europaeus L.)*, підбіл звичайний (Tussilago farfara L.), плетуха звичайна (Calystegia sepium (L.) R. Br.)*, вербозілля звичайне (Lysimachia vulgaris L.)*, скажений огірок звичайний (Ecballium elaterium (L.) A. Rich), щавель прибережний

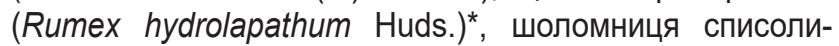
ста (Scutellaria hastifolia L.), паслін чорний (Solanum nigrum L.), подорожник великий (Plantago major L.)*, герань лучна (Geranium pratense L.).

3 обох боків водотоку в смузі шириною 10-20 м представлена вологолюбна деревна та чагарникова рослинність. Домінантами виступають вільха чорна (Alnus glutinosa (L.) Gaertn.)*, верба п'ятитичинкова (Salix pentandra L.)*, верба козяча (Salix caprea L.)*. Спорадично трапляються осика звичайна (Populus tremula L.)*, маслинка вузьколиста (Elaeagnus angustifolia L.), верба ламка (Salix fragilis L.), тополя біла (Populus alba L.)*, береза повисла (Betula pendula Roth.)* ${ }^{*}$ клен американський (Acer negundo L.), в'яз гладкий (Ulmus laevis L.)*. Подекуди ростуть поодинокі рослини сосни звичайної (Pinus sylvestris L.)*, горобини звичайної (Sorbus aucuparia L.)*, груші звичайної (Pyrus communis L.)*, глоду колючого (Crataegus oxyacantha L.), клену польового (Acer campestre L.), дуба звичайного (Quercus robur L.)*. Повнота деревостану складає 0,5. У ярусі чагарників зростають бузина чорна (Sambucus nigra L.), верба тритичинкова (Salix triandra L.)*, рідше - верба розмаринолиста (Salix rosmarinifolia L.) та глід український (Crataegus ucrainica Pojark.). Два останніх види належать до тих, що підлягають особливій охороні на території Сумської області. Під наметом деревно-чагарникової рослинності домінує костриця лучна (Festuca pratensis Huds.) з проективним покриттям 40 \%. Серед тіньовитривалих трав переважають угруповання яглиці звичайної (Aegopodium podagraria L.), розрив-трави звичайної (Impatiens noli-tangere L.)*, кропиви дводомної (Urtica dioica L.)*, чистотілу звичайного (Chelidonium majus L.), кропиви жалкої (Urtica urens L.), болиголову плямистого (Conium maculatum L.), підмаренника чіпкого (Galium aparine L.), поодиноко трапляється папороть чоловіча (Dryopteris filix-mass (L.) Schott). На галявинах сформовані угруповання таких видів як гадючник в'язолистий (Filipendula ulmaria (L.) Maxim.)*, куничник наземний (Calamagrostis epigeios L.). Подекуди тра- пляється будяк пониклий (Carduus nutans L.), лопух справжній (Arctium lappa L.), морква дика (Daucus carota L.), дивина чорна (Verbascum nigrum L.), пижмо звичайне (Tanacetum vulgare L.), золотушник канадський (Solidago canadensis L.), розхідник звичайний (Glechoma hederacea L.). По деревах плетуться зарості хмелю звичайного (Humulus lupulus L.) та дівочого винограду п'ятилисточкового (Parthenocissus quinquefolia (L.) Planch.).

Загалом, у межах досліджуваної території у водоймі та прибержній смузі р. Сироватки зростає 41 вид, включений до «Червоного списку МСОП» (тут і далі за текстом їх відзначено позначкою «*»). При цьому 40 видів мають категорію раритетності рівня LC (знаходяться під найменшою загрозою) та один (Ulmus laevis Pall.) - ще нижчий охоронний статус (рівня DD: данних недостатньо). Виявлено і два види, занесені до «Переліку видів, які підлягають особливій охороні на території Сумської області».

На високих ділянках корінного правого берега розташовані лучні та лісові угруповання. У лісовому масиві біля озера у першому ярусі домінує $P$. sylvestris* віком 50-60 років з проективним покриттям $90 \%$, формуючи сухий бор. Зімкнутість першого деревного ярусу здебільшого становить 0,8-0,9. В другому ярусі домінує Robinia pseudoacacia L., подекуди трапляється Corylus avellane L., B. pendula*, U. laevis*, Q. robur *, P. tremula*.

У трав'яному ярусі соснового лісу домінують тонконіг дібровний (Poa nemoralis L.) з проективним покриттям $30 \%$ та осока шорстковолосиста (Carex hirta L.). Проективне покриття інших видів не перевищує 3-6 \% - куртинами розкидані угруповання мітлиці собачої (Agrostis canina L.) та костриці овечої (Festuca ovina L.), подекуди трапляється мітлиця повзуча (Agrostis stolonifera L.)*, C. epigeios, пирій повзучий (Elytrigia repens (L.) Gould.), Lysimachia vulgaris*, молочай лозний (Euphorbia virgata Waldst. \& Kit.), Tanacetum vulgare, гравілат міський (Geum urbanum L.), звіробій звичайний (Hypericum perforatum L.), поодиноко - грабельки звичайні (Erodium cicutarium (L.) L'Her.), нечуйвітер волохатенький (Pilosella officinarum F.W. Schultz \& Sch. Вip.). В південній та східній частинах соснового лісу знайдено два локалітети півників борових (Iris pineticola Klokov) загальною площею 13 м², занесених до Червоної книги України. В південно-західній частині лісового масиву значну площу займає угруповання купини багатоквіткової (Polygonatum multiflorum (L.) All.). B пониженнях рельєфу трапляються хвощ польовий (Equisetum arvense L.) ${ }^{*}$, безщитник жіночий (Athyrium filix-femina (L.) Roth ex Mert.) та Dryopteris filix-mass (L.) Schott.

Отже, у складі лісових фрітоценозів, що займають підвищені ділянки долини р. Сироватки, та фітоценозів суходільних луків з яскраво вираженим процесом самозаліснення виявлено сім видів рослин, які включено до «Червоного списку МСОП». шість із них (за винятком Ulmus laevis) мають ранг охорони рівня LC. Тут зростає один вид, включений до «Червоної книги України».

Найбільшу площу у межах досліджуваної території займають заплавні луки. Домінантами лучної рослинності виступають Carex hirta - місцями із проективним покриттям до $50 \%$, Epilobium palustre* - до $10 \%$. Значною 
мірою (при проективному покритті 3-5 \%) представлені щучка дерниста (Deschampsia caespitosa (L.) P. Beauv.), Calamagrostis epigeios, Festuca pratensis, Dactylis glomerata, Poa pratensis*, стоколос безостий (Bromopsis inermis Leyss.), райграс пасовищний (Lolium perenne L.), тимофіївка лучна (Phleum pratense L.), перстач повзучий (Potentilla reptans L.), осот польовий (Cirsium vulgare (Savi) Ten.), осот жовтий (Sonchus arvensis L.), латук дикий (Lactuca serriola L.), скереда покрівельна (Crepis tectorum L.), герань лучна (Geranium pratense L.), осока рання (Carex praecox Schreb.), Carex acutiformis*, пастернак дикий (Pastinaca sylvestris Mill.), морква дика (Daucus carota L.), Solidago canadensis, Elytrigia repens, Equisetum arvense*, парило звичайне (Agrimonia eupatoria L.), Trifolium pratense*, Trifolium repens.

Не більше 1-2 \% проективного покриття лучного різноманіття займають такі трави, як цикорій дикий (Cichorium intybus L.), конюшина середня (Trifolium medium L.), люцерна жовта (Medicago falcata L.), горошок мишачий (Vícia cracca L.), Plantago major *, деревій звичайний (Achillea millefolium L.) ${ }^{*}$, злинка канадська (Erigeron canadensis L.), жовтець їдкий (Ranunculus acris L.), підмаренник справжній (Galium verum L.), кульбаба лікарська (Taraxacum officinale Webb. ex F.H.Wigg.), лобода біла (Chenopodium album L.), амброзія полинолиста (Ambrosia artemisifolia L.), чистець болотний (Stachys palustris L.)*, костриця овеча (Festuca ovina L.), E. virgata, щавель кислий (Rumex acetosa L.).

Окремими групами зростають Eupatorium cannabinum, живокіст лікарський (Symphytum officinale L.), щавель кінський (Rumex confertus Willd.), полин звичайний (Artemisia vulgaris L.), конюшина суницевидна (Trifolium fragiferum L.), Tussilago farfara, будяк акантовидний (Carduus acanthoídes L.), татарник звичайний (Onopordum acanthium L.), Arctium lappa, оман британський (Pentanema britannicum (L.) D. Gut. Larr.), Potentilla anserina*, дзвінець великий (Rhinanthus angustifolius C.C.Gmel.), Plantago major*. Таким чинном, у формуванні трав'янистих фітоценозів заплавних лук беруть участь вісім видів рослин, включених до «Червоного списку МСОП» із охоронним статусом рівня LC.

Обговорення. Результати вивчення фіторізноманіття однієї із ділянок долини р. Сироватка свідчать про те, що цій території притаманне значне видове багатство: тут зростають рослини, які мають різні ранги охорони (регіональ- ний, державний, міжнародний). Група видів міжнародного рангу охорони є найбільшою, її формують рослини, включені до «Червоного списку МСОП». Майже усі вони (окрім одного) мають невисокий охоронний статус (LC). Значним $€$ і ценотичне різноманіття, репрезентоване угрупованнями водної, повітряно-водної, лучної та лісової рослинності.

Багате фріторізноманіття у комплексі із рівнинністю території та білизкістю до населених пунктів, у тому числі і до м. Суми, формують об'єктивне підгрунтя щодо залучення цієї території до туристичної, рекреаційної та еколого-просвітницької діяльності. За таких умов актуальності набуває питання щодо розробки тактики та стратегії реалізації зазначених заходів, у тому числі розробки маршрутів, еколого-туристичних стежок, їхнього маркування та облаштування, виготовлення рекламної продукції, дотримання вимог техніки безпеки та природохоронного законодавства.

3 метою поглиблення знань про формування, сучасний стан та динаміку розвитку природних комплексів долини р. Сироватки необхідно продовжити геоботанічні та зоологічні дослідження території. Окрім того, доцільно привести лісовий масив в естетично-привабливий стан, зокрема, видалити смітники з подальшим облаштуванням рекреаційних зон. 3 врахуванням багатого біорізноманіття території доцільно розглянути і питання щодо надання цій території природохоронного статусу з обранням категорії, яка дозволить як поліпшити охорону рослинного і тваринного світу, так і надасть можливість реалізовувати рекреаційну та туристичну діяльність.

Висновки. Дослідження фіторізноманіття заплави р. Сироватки виявило природні комплекси, які цілком можливо використовувати в екологічному туризмі. Досить високий рівень різноманіття і відносно значний ступінь антропогенної трансформованості - характерні ознаки природи досліджуваної території.

Незважаючи на виявлення основних показників щодо складу і стану природних комплексів території, питання подальшого її дослідження не втрачає актуальності. Особливу увагу необхідно приділяти аспектам антропогенного впливу на стан, зміни тих чи інших компонентів природних комплексів. За умови активного залучення цієї території до туристичної та рекреаційної діяльності буде зростати і значущість впровадження моніторингових досліджень за станом фіторізноманіття, його динамікою під впливом цих видів антропогенного впливу.

\section{Бібліографічні посилання:}

1. Barkin, D., \& Bouchez, C. P. (2002). NGO-Community Collaboration for Ecotourism: A Strategy for Sustainable Regional Development. Current Issues in Tourism, 5(3-4), 245-253. doi: 10.1080/13683500208667921

2. Bashtovyi, M. H., Skliar, V. H., Tykhonova, O. M., \& Skljar, Ju. L. (2018). Turistychny claster Sumshiny: geomonitoring obektiv ekologichno-orientovanogo turismu yak skladova stalogo rozvitku regionu [Sumy region tourism cluster: geomonitoring of ecologically oriented tourism objects as a component of sustainable development of the region]. Visnyk Sumskogo universytetu, Economics and management, 8(77), 143-148 (in Ukrainian).

3. Bondarieva, L. M., Kyrylchuk, K. S., Skliar, V. H., Tykhonova, O. M., Zhatova, H. O., \& Bashtovyi, M. G. (2019). Population dynamics of the typical meadow species in the conditions of pasture digression in flooded meadows. Ukrainian Journal of Ecology, 9(1), 204-211.

4. Burger, J. (2000). Landscapes, tourism, and conservation. Science of the Total Environment, 249(1-3), 39-49. doi: 10.1016/s0048-9697(99)00509-4.

5. Cardinale, B. J., Matulich, K. L., Hooper, D. D., Byrnes, J. E., Duffy, E., Gamfeldt, L., Balvanera, P., O'Connor, M.I. \& Gonzalez, A. (2011). The functional role of producer diversity in ecosystems. American Journal of Botany, 98(3), 572-592. doi: 10.3732/ajb.1000364 
6. Copylec', Je. V. (2009).Traktuvannja ponjattja ekologichnyh cinnisnyh orijentacij u teorii' ekologichnoi' osvity i vyhovannja [Interpretation of the concept of ecological value orientations in the theory of ecological education and upbringing]. Slov'jans'k: SDPU, 14,184 - 188 (in Ukrainian).

7. Dmytruk, O. Ju., \& Shhur, Ju. V. (2002). Ekologichnij turizm jak didaktichna osnova racional'nogo prirodokoristuvannja ta geoekologichnoi' osviti [Ecological tourism as a didactic basis of rational nature management and geoecological education]. Regional'ni ekologichni problemi, 36, 45-50 (in Ukrainian).

8. Dupuy, P., \& Viñuales, J. (2018). International Environmental Law (2nd ed.). Cambridge University Press, Cambridge, 594. doi: $10.1017 / 9781108399821$

9. Geologicheskij ocherk Sumskoj oblasti [Geological feature article of the Sumy region] (1947). Red. D. N. Soboleva, L. I. Karjakina, I. P. Cherneckogo. Sumy, Bil'shovic'ka zbroja, 375 (in Russian).

10. Hunt, C. A., Durham, W. H., Driscoll, L., Honey, M. (2015). "Can ecotourism deliver real economic, social, and environmental benefits? A study of the Osa Peninsula, Costa Rica". Journal of Sustainable Tourism, 23(3), 339-357. doi: 10.1080/09669582.2014.965176. ISSN 0966-9582. S2CID 55684006.

11. Honey, M. (2008). Ecotourism and Sustainable Development: Who Owns Paradise? (Second ed.). DC: Island Press, Washington, ISBN 978-1-59726-125-8.

12. Kaur, A. (2018) Conservation of Plant Biodiversity Current Strategies and Future Needs. International Journal of Scientific Research in Biological Sciences, 5(4), 109-113. doi: 10.26438/ijsrbs/v5i4.109113

13. Klymenko, G. O., Zlobin, Ju. A., \& Bjelan, S. S. (2011). Shljahy vdoskonalennja ohorony ridkisnyh vydiv roslyn v Ukrai'ni [The ways of improving protection of rare plant species in Ukraine]. Vcheni zapysky Tavrichnogo nacional'nogo universytetu im. V. I. Vernads'kogo. Ser. Biologija ta himija, 24(63), 1, 52-59 (in Ukrainian).

14. Kozenja, E. Y. (2005). K sushhnosty voprosa ob ekologycheskom soznanyy [To the essence of the question of environmental consciousness]. Aktual'ni problemy psyhologii': zb. nauk. prac', 7(5), 1, 214-218 (in Russian).

15. Korovjakova, T. O., \& Tyhonova, O. M. (2015). Cenopopuljacii' invazijnogo vydu Stenactis (Phalacroloma) annua (L). Cass. na zaplavnyh lukah richky Psel (Sums'ka oblast') [Cenopopulations of invasive species Stenactis (Phalacroloma) annua (L). Cass. on floodplain meadows of the river Psel (Sumy region)]. Visnyk Cherkas'kogo universytetu, 2(335), 60-66 (in Ukrainian).

16. L'ovochkina, A. M. (2003). Ekologichna psyhologija. Navchal'nyj posibnyk [Environmental Psychology: A Textbook]. Milenium, K., 120 (in Ukrainian).

17. Mace, G. M., Norris, K., \& Fitter, A. H. (2012). Biodiversity and ecosystem services: a multilayered relationship. Trends in Ecology and Evolution, 27(1),19-26. doi: 10.1016/j.tree.2011.08.006

18. Marynych, O. M., Parhomenko, G. O., Petrenko, O. M., \& Shyshhenko, P. G. (2003). Udoskonalena shema fizykogeografichnogo rajonuvannja Ukrai'ny [Improved scheme of physical and geographical zoning of Ukraine]. Ukr. geograf. zhurn.,1, 16-20 (in Ukrainian).

19. Posohov, I. S., \& Sagaidachna, A. V. (2019). Perspektyvi rozvytku ecologichnogo turyzmu v Ukraini [Prospects for the development of ecological tourism in Ukraine]. Visnyk Harkivskogo universytetu. International Relations. Economics. Country Studies. Tourism, 9, 203-212. (in Ukrainian). doi: 10.26565/2310B9513B2019B9B25

20. Rahman, M. A. (2018) Plant diversity in Hazarikhil Wildlife Sanctuary of Chittagong and its conservation management. Journal of Biodiversity Conservation and Bioresource Management, 3(2), 43-56. doi: 10.3329/jbcbm.v3i2.36027

21. Salk, C. F., Chazdon, R., \& Waiswa, R. (2020). Thinking outside the plot: monitoring forest biodiversity for socialecological research. Ecology and Society, 25(1), 7. doi: 10.5751/ES-11223-250107

22. Segelbacher, G. (2018). Genetic, genomic, synthetic - new approaches for biodiversity conservation. Proceedings of the 5th European Congress of Conservation Biology. ECCB2018: 5th European Congress of Conservation Biology. 12th - 15th of June 2018, Jyväskylä, Finland. doi: 10.17011/conference/eccb2018/107508

23. Skliar, V. G., Skliar, Ju. L., Gudakov, O. O., \& Tykhonova, O. M. (2012). Harakterystyka pryrodnyh kompleksiv Get'mans'kogo nacional'nogo pryrodnogo parku [Characteristics of natural systems of the Getmanski National Nature Park]. Visnyk Sums'kogo NAU. Serija «Agronomija i biologija», 2(23), 13-17 (in Ukrainian).

24. Skliar, V. G., Jemec', O. M., \& Skliar, Ju. L. (2020). Bioriznomanittja proektovanogo zakaznyka «Kalii'vs'kyj» [Biodiversity of the projected reserve "Kaliyivsky"]. Monitoryng ta ohorona bioriznomanittja v Ukrai'ni : prykladni aspekty monitoryngu ta ohorony bioriznomanittja. «Conservation Biology in Ukraine». Druk Art, Kyi'v ; Chernivci,16(3), 441-444 (in Ukrainian).

25. Skliar, V. H. (2014). Pryrodne vidnovlennia providnykh lisoutvoriuvalnykh vydiv Novhorod-Siverskoho Polissia: realizovani ekolohichni nishi ta yikhnia dynamika [Natural restoration of the leading forest-forming species of NovgorodSiversky Polissya: realized ecological niches and their dynamics]. Ukr. botan. Journal, 71 (1), 8-16 (in Ukrainian).

26. Skrebec', V. O. (2005). Suchasnyj stan ta priorytetni naprjamy rozvytku ekologichnoi' psyhologii' v Ukrai'ni [Current state and priority directions of development of ecological psychology in Ukraine]. Aktual'ni problemy psyhologii'. Zb. nauk. pr., 5(2), 235- 245 (in Ukrainian).

27. Sheljag-Sosonko, Ju. R. (1971). Formacija duba zvychajnogo (Querceta roboris) Livoberezhnogo rel'jefnogo lisostepu Ukrai'ny [Formation of common oak (Querceta roboris) of the Left-bank relief forest-steppe of Ukraine]. Ukr. botanichnyj zhurnal, 28(3), 356-361 (in Ukrainian).

28. Sui, X., Mao, L., Liu, Y., \& He, F. (2018). Mapping relative extinction risk for biodiversity conservation. Biological Conservation, 226, 168-176. doi: 0.1016/j.biocon.2018.07.012

29. Wilsey, B. J. (2018). Biodiversity of Grasslands. Oxford Scholarship Online. doi: 10.1093/oso/9780198744511.003.0002 
Skliar V. G. Doctor (Biological Sciences), Professor, Sumy National Agrarian University, Sumy, Ukraine

Tykhonova O. M., PhD (Biological Sciences), Associate Professor, Sumy National Agrarian University, Sumy, Ukraine

Kyrylchuk K. S., PhD (Biological Sciences), Associate Professor, Sumy National Agrarian University, Sumy, Ukraine

Klymenko H. O., PhD (Biological Sciences), Associate Arofessor, Sumy National Agrarian University, Sumy, Ukraine

Onoprienko V. P. Doctor (Pedagogical Sciences), Professor, Sumy National Agrarian University, Sumy, Ukraine

Bondarieva L. M., PhD (Biological Sciences), Associate Professor, Sumy National Agrarian University, Sumy, Ukraine

Trotska S. S., PhD (Biological Sciences), Senior Lecturer, Sumy National Agrarian University, Sumy, Ukraine

Klimenko Ju. O., Student, Sumy National Agrarian University, Sumy, Ukraine

Study of phytodiversity of the Syrovatka river valley with the perspective of using its natural complexes in ecological tourism

The paper presents the results of studying the phytodiversity of natural complexes of the Syrovatka river valley between the villages of Verkhnya Syrovatka and Novoselytsia of Sumy district. It is shown that this area is characterized by significant species wealth: here grow plants that have different ranks of protection (regional, state, international). The group of species of international protection is the largest and includes about 50 species. It is formed by plants included in the IUCN Red List. Almost all of them (except one) have a low protection status (LC - are at the lowest risk). Among the species included in the "Red Book of Ukraine", a small population of Iris pineticola Klokov was found, and among the plants presented in the "List of species subject to special protection in the Sumy region" - Salix rosmarinifolia L. and Crataegus ucrainica Pojark. The coenotic diversity represented by groups of aquatic, air-water, meadow and forest vegetation is also significant. Rich phytodiversity in combination with the flatness of the territory and whiteness to the settlements, including the city of Sumy, form an objective basis for the involvement of this area in tourism, recreation and environmental education. The most promising is the introduction of eco-tourism, which combines economic, social and environmental issues. In order to deepen knowledge about the formation, current state and dynamics of development of natural complexes of the Syrovatka river valley, it is necessary to continue geobotanical and zoological research of the territory. In addition, it is advisable to bring the forest into an aesthetically pleasing condition, in particular, to remove landfills. Taking into account the rich biodiversity of the territory, it is expedient to consider the issue of granting this territory environmental status with the choice of a category that will improve both the protection of flora and fauna and provide opportunities for recreational and tourist activities.

Key words: phytodiversity, environment, ecological tourism, human ecology, natural landscapes. 